УДК 242.9:347.77

DOI https://doi.org/10.32837/yuv.v0i1.1650

\title{
В. Шморгун,
}

здобувач

Науково-дослідного інституту публічного права

\section{НОРМАТИВНО-ПРАВОВЕ РЕГУЛЮВАННЯ АДМІНІСТРАТИВНОЇ ВІДПОВІДАЛЬНОСТІ У СФЕРІ НЕЗАКОННОГО ВИКОРИСТАННЯ ЗАСОБІВ ІНДИВІДУАЛІЗАЦІЇ УЧАСНИКІВ ГОСПОДАРСЬКОГО ОБОРОТУ, ТОВАРІВ І ПОСЛУГ}

Особливістю сучасного стану нормативно-правового регулювання адміністративної відповідальності за незаконне використання засобів індивідуалізації учасників господарського обороту, товарів і послуг є те, що основним нормативно-правовим актом у зазначеній сфері $€$ Кодекс Украіни про адміністративні правопорушення (далі - КУпАП), нормами якого передбачено адміністративну відповідальність. Проте здійснений аналіз нормативно-правового регулювання адміністративної відповідальності за порушення прав на торговельні марки, комерційні найменування, географічні зазначення свідчить, що такі положення містяться в нормах Митного кодексу України, Податкового кодексу України та інших законодавчих актах. Це означає, що роль адміністративної відповідальності в досліджуваній сфері постійно зростає, водночас питання законодавчого регулювання адміністративної відповідальності незаконного використання засобів індивідуалізації учасників господарського обороту, товарів і послуг є малодослідженим у правовій доктрині. Тому вивчення вказаного питання є, безперечно, актуальним, враховуючи важливість охорони прав засобів індивідуалізації.

Адміністративну відповідальність у межах охорони прав інтелектуальної власності досліджували зокрема В. Галунько, Т. Гарбуз, О. Коро- тун, О. Кульчицька, А. Майданевич, О. Світличний, О. Тандир та інші. Водночас жодна з їхніх праць не розкрила питання сучасного стану нормативно-правового регулювання адміністративної відповідальності за незаконне використання засобів індивідуалізації учасників господарського обороту, товарів і послуг.

Метою статті є дослідження визначення законодавчих актів, норми яких передбачають адміністративну відповідальність за незаконне використання засобів індивідуалізації учасників господарського обороту, товарів і послуг.

Сучасні пріоритети охорони прав i законних інтересів правовласників та інших учасників правовідносин у сфері охорони засобів індивідуалізації учасників господарського обороту, товарів і послуг від їx незаконного використання є такими, що потребують впливу держави на наявні проблеми, пов'язані 3 ефективністю охорони й захисту цих прав, що безпосередньо залежить від дієвості нормативно-правової бази [1, с. 84$]$.

Відповідно до загальної теорії права нормативне регулювання - це впорядкування поведінки людей за допомогою нормативно-правових актів, розрахованих на їх багаторазове використання за наявності передбачених ними обставин [2, с. 218].

Важливою складовою законодавчого регулювання адміністративної 
відповідальності є п. 22 ст. $92 \mathrm{KoH}-$ ституції України, згідно з яким засади цивільно-правової відповідальності, діяння, які $€$ злочинами, адміністративними або дисциплінарними правопорушеннями, та відповідальність за них визначаються виключно законами України [3].

Нормами Основного Закону визначено, що адміністративному законодавству відводиться значна роль у забезпеченні захисту інтелектуальної власності. Крім адміністративного законодавства, важливу роль у забезпеченні охорони прав інтелектуальної власності відіграють також інші законодавчі акти, норми яких регулюють правові питання, пов'язані з інтелектуальною власністю.

На думку Є. Додіна, нормативно-правове регулювання адміністративної відповідальності складається з цілісної сукупності нормативно-правових актів, що містять основний масив норм національного права, єдність якого забезпечено, насамперед, установленими в Конституції принципами, іншими вихідними положеннями та яке складається 3 інститутів, функціонально орієнтованих на досягнення цілей та ідеалів, позначених в іiі центральній підсистемі - законодавстві [4, с. 71]. Разом із тим не можна не звернути увагу на той факт, що межі адміністративно-правової охорони нормативно-правового регулювання незаконного використання засобів індивідуалізації учасників господарського обороту, товарів і послуг охоплюються не тільки нормами адміністративного законодавства, але й іншими нормативними актами, нормами яких передбачена юридична відповідальність з приводу такої діяльності.

Особливістю сучасного стану нормативно-правового регулювання адміністративної відповідальності за незаконне використання засобів індивідуалізації учасників господарського обороту, товарів і послуг є те, що основним нормативно-правовим актом у зазначеній сфері є КУпАП, нормами якого передбачена адміністративна відповідальність. Незважаючи на те що засоби індивідуалізації адміністративно-правової охорони об'єднані за родовою (інтелектуальною) ознакою (торговельні марки, комерційні найменування, географічні зазначення), вони безпосередньо стосуються об'єктів права інтелектуальної власності, розміщених у різних главах КУПАП. Це ст. ст. 51-2, 156-3, 164-3 КУПАП [5]. На нашу думку, доцільно норми вказаних статей об'єднати в одну статтю й одну главу адміністративного кодексу.

На сьогодні адміністративну відповідальність у досліджуваній сфері, крім КУпАП, передбачають також інші законодавчі акти, зокрема Митний кодекс України (далі - MK України) від 13 березня 2012 р. № 4495-VI [6], Податковий кодекс України (далі - ПК України) від 2 грудня 2010 р. № 2755-VI [7] та інші законодавчі акти.

До недоліків MK України слід віднести те, що його норми не повною мірою охоплюють захист об'єктів права інтелектуальної власності на митному кордоні. Як зазначає С. Филь, такі об'єкти права інтелектуальної власності, як наукові відкриття, компонування (топографіi) інтегральних мікросхем, раціоналізаторські пропозиціі, породи тварин, фірмові найменування, комерційні таємниці, не належать до компетенції митниць. Така юридична колізія порушує гарантовані Конституцією України права людини на захист прав інтелектуальної власності [8, с. 7].

До законодавчих актів, норми яких передбачають адміністративну відповідальність об'єктів права інтелектуальної власності, слід віднести:

1) ПК України, в пп. 14. 1. 225 ст. 14 якого зазначено, що за користування або за надання права на користування будь-яким авторським i суміжним правом на літературні твори, твори мистецтва або науки, включаючи комп'ютерні програми, інші записи на носіях інформації, відео- або аудіокасети, кінематографічні фільми або плівки для радіо- чи телевізійного 
мовлення, захищені будь-яким патентом, зареєстрованим знаком на товари й послуги чи торговельною маркою, дизайном, секретним кресленням, моделлю, формулою, процесом, правом на інформацію щодо промислового, комерційного або наукового досвіду (ноу-хау), отриманим як винагороду, особи платять роялті [7].

Разом із тим ми не можемо не звернути увагу на ст. 217 Господарського кодексу України (далі - ГК України), норми якого встановлюють відповідальність у сфері господарювання. Згідно зі ст. 239 ГК України органи державної влади відповідно до своїх повноважень i в установленому законом порядку можуть застосовувати до суб'єктів господарювання адміністративно-господарські санкції [9].

Наведений у ст. 239 ГК України перелік приписів адміністративно-господарських санкцій свідчить, що не всі елементи $є$ характерними для адміністративної відповідальності; водночас деякі елементи (нерівність сторін; застосування штрафу, що тягне несприятливі наслідки для порушника; накладання штрафу уповноваженим державним органом, його посадовою особою; спрощена процедура накладання штрафу) є характерними для адміністративної відповідальності.

3 приводу господарсько-правової відповідальності О. Зима зазначає, що ГК України можна назвати не лише законом, який офіційно визнав адміністративну відповідальність юридичних осіб, а й першим кодифікованим актом, що містить загальні положення щодо такої відповідальності. Щоб забезпечити ефективне функціонування розглянутого виду адміністративної відповідальності, слід установити чіткий перелік юрисдикційних органів, а також загальні правила притягнення юридичних осіб до адміністративної відповідальності. Надалі, щоб забезпечити ефективне функціонування розглянутого виду адміністративної відповідальності, слід установити чіткий перелік юрисдикційних органів, а також загальні правила притягнення юридичних осіб до адміністративної відповідальності. Стан справ сьогодні, коли в кожного державного органа розроблений свій окремий і здебільшого дуже недосконалий порядок накладання адміністративних стягнень (розгляду справ про адміністративні правопорушення з боку юридичних осіб), а в багатьох випадках він узагалі відсутній, є незадовільним [9, с. 195].

3 огляду на викладене принагідно зазначимо, що на сьогодні законодавство про адміністративну відповідальність є розрізненим і потребує кодифікації. Водночас варто звернути увагу, що 3 метою охорони прав на засоби індивідуалізації уповноважені органи та їхні посадові особи застосовують різноманітні адміністративні методи безпосереднього й цілеспрямованого впливу на підпорядковані об’єкти, що не виключає застосування адміністративного примусу [10, с. 36].

Що стосується предмета нашого дослідження, то адміністративна відповідальність за незаконне використання засобів індивідуалізаціі учасників господарського обороту, товарів і послуг, крім КУпАП, передбачена нормами таких Законів України: «Про рекламу» [11]; «Про державне регулювання виробництва і обігу спирту етилового, коньячного і плодового, алкогольних напоїв, тютюнових виробів та пального» [12]; «Про заходи щодо попередження та зменшення вживання тютюнових виробів і їх шкідливого впливу на здоров'я населення» [13]; «Про захист економічної конкуренції» [14]; «Про захист від недобросовісної конкуренції [15]. Норми вказаних законів вказують, що за порушення торговельних марок, комерційних найменувань, географічних зазначень винні особи несуть юридичну, в тому числі й адміністративну, відповідальність, до них застосовуються штрафи й інші фінансові санкції.

Штраф, який накладається за вчинене правопорушення, $є$ адміністративним правопорушенням, яке $є$ підставою 
для застосування адміністративної відповідальності.

3 вищевикладеного зрозуміло, що нормативно-правове регулювання адміністративної відповідальності у сфері незаконного використання засобів індивідуалізації учасників господарського обороту, товарів і послуг, крім КУПАП, що регулює питання встановлення адміністративної відповідальності, здійснюється й іншими нормативно-правовими актами, які в сукупності також слід віднести до законодавчих актів, норми яких передбачають адміністративну відповідальність у досліджуваній сфері.

Незважаючи на закріплені в багатьох законодавчих актах різного виду стягнення (штраф, фінансовий штраф) нормативною основою адміністративної відповідальності переважно $є$ норми адміністративного законодавства. На це вказують норми адміністративного, митного й податкового законодавства.

Акцентуючи увагу на адміністративній відповідальності, ми не можемо не звернути увагу на процесуальний характер захисту засобів індивідуалізації.

В контексті нашого дослідження потрібно зазначити, що згідно зі ст. 255 КУПАП право складати протоколи про адміністративні правопорушення, передбачені ст. ст. 51-2, 156-3, 164-3 КУпАП, мають право органи Міністерства внутрішніх справ (ст. ст. 51-2, 164-3;) органи Антимонопольного комітету України (ст. 164-3); органи Державної податкової служби (ст. 51-2); державні інспектори з питань інтелектуальної власності (ст. 51-2); державні інспектори сільського господарства (ст. 51-2) [5].

Разом із тим не можна не звернути увагу, що питання адміністративної відповідальності регулюється й підзаконними нормативними актами. Зокрема актом, який передбачає застосування адміністративних санкцій у досліджуваній сфері, є «Порядок накладення штрафів за порушення законодавства про рекламу», затверджений Поста- новою Кабінету Міністрів України від 26 травня 2004 р. № 693 [16].

Резюмуючи викладене вище, можна стверджувати, що нормативно-правові акти регулювання адміністративної відповідальності у сфері незаконного використання засобів індивідуалізації учасників господарського обороту, товарів і послуг можна класифікувати за нормами, які передбачають відповідальність за порушення прав: 1) на торговельну марку (знак для товарів і послуг); 2) на комерційні (фірмові) найменування; 3) на географічні зазначення.

Адміністративна відповідальність за незаконне використання засобів індивідуалізації учасників господарського обороту, товарів і послуг передбачена в нормах Кодексу України про адміністративні правопорушення, Митного кодексу України, Податкового кодексу України, Господарського кодексу Украіни, Законах України «Про рекламу», «Про державне регулювання виробництва і обігу спирту етилового, коньячного і плодового, алкогольних напоїв, тютюнових виробів та пального», «Про заходи щодо попередження та зменшення вживання тютюнових виробів i ïх шкідливого впливу на здоров'я населення», «Про захист від недобросовісної конкуренції», «Про захист економічної конкуренції».

Роль адміністративної відповідальності в досліджуваній сфері постійно зростає, про це свідчать склади адміністративних правопорушень зазначених актів.

Отже, нормативно-правове регулювання адміністративної відповідальності в досліджуваній сфері визначаємо як впорядковану систему взаємопов'язаних нормативно-правових актів, які встановлюють адміністративно-правові заходи 3 метою охорони прав правовласників об'єктів права інтелектуальної власності й інших учасників правовідносин у сфері незаконного використання засобів індивідуалізаціï учасників господарського обороту, товарів і послуг. 


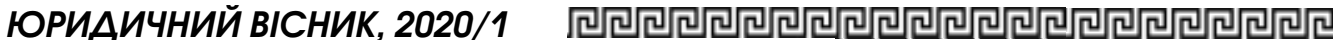

У статті досліджено важливу роль національного законодавства України у сфері охорони засобів індивідуалізації учасників господарського обороту, товарів $i$ послуг. Звертається увага на те, що серед значної кількості об’єктів права інтелектуальної власності своєю специфічністю вирізняються торговельні марки, комеризійі найменування, географічні зазначення, які ми відносимо до засобів індивідуалізації учасників господарського обороту, товарів $i$ послуг. 3 a допомогою засобів індивідуалізації учасників господарського обороту, товарів $i$ послуг декілька суб'єктів господарської діяльності виробляють одну й ту саму продукцію, надають послуги одного виду, щз можуть бути різними як за иіною, так $i$ за якістю, надають споживачеві можливість відрізнити один i той самий товар або послугу однієї особи від такого ж товару (послуги), щуо виробляеться різними суб'ектами господарювання.

Вказані засоби індивідуалізації підлягають охороні значною кількістю законодавчих актів, серед яких одне з провідних місиь посідає сучасне адміністративне законодавство. Пріоритети охорони прав $i$ законних інтересів особи сьогодні потребують від держави, ї уповноважених органів і посадових осіб забезпечити належну охорону суб'єктивних прав власників об'єктів права інтелектуальної власності та інших учасників правовідносин у сфері охорони засобів індивідуалізації учасників господарського обороту, товарів $i$ послуг від їх незаконного використання.

Серед нормативних актів, щз регулюють правовідносини у сфері інтелектуальної власності, провідна роль належить Конституизї України, яка має найвищу юридичну силу: ст. 41 Конституції проголошуе право кожного володіти, користуватися й розпоряджатися своєю власністю, результатами своєї інтелек- туальної, творчої діяльності, а cm. 54 гарантує свободу творчості й захист прав інтелектуальної власності, моральних $i$ матеріальних інтересів, шо виникають у зв'язку з різними видами інтелектуальноі діяльності. Вказане знайшло своє відображення в Кодексі України про адміністративні правопорушення, одним із завдань якого є охорона прав інтелектуальної власності.

Ключові слова: законодавство, кодекс, інтелектуальна власність, охорона.

Shmorgun V. Regulatory and legal regulation of administrative liability in the area of illegal use of individualization of tacopariars

The article examines the important role of the national legislation of Ukraine in the sphere of protection of the means of individualization of participants of economic turnover, goods and services. Attention is drawn to the fact that trademarks, business names, geographical indications, which we refer to as means of individualization of participants in economic turnover, goods and services, through which several business entities produce one, are distinguished by a significant number of objects of intellectual property rights. and the same products, provide services of the same kind, which can be different, both in price and in quality, give the consumer the opportunity to distinguish the same product, or after huga one person from the same product (service), which is produced by different entities through the means of individualization of participants in economic turnover, goods and services.

These means of individualization are subject to protection by a large number of legislative acts, among which one of the leading places is the current administrative legislation. Current priorities for the protection of the rights and legitimate interests of the person require the state of its authorized bodies and officials to ensure proper 
protection of the subjective rights of the owners of intellectual property rights and other participants of legal relations in the field of protection of the means of individualization of participants in economic turnover, goods and services illegal use.

Among the normative acts regulating legal relations in the field of intellectual property, the leading role is played by the Constitution of Ukraine, which has the highest legal force, Art. 41 of the Constitution proclaims the right of everyone to own, use and dispose of their property, the results of their intellectual, creative activity, and Art. 54 guarantees the freedom of creativity and the protection of intellectual property, moral and material interests arising from various types of intellectual activity. This was reflected in the Code of Administrative Offenses, one of the tasks of which is the protection of intellectual property rights.

Key words: legislation, code, intellectual property, protection.

\section{Лiтература}

1. Коротун О.М. Адміністративно-правові аспекти забезпечення охорони прав суб'єктів інтелектуальної власності в Україні: проблеми теорії та практики правозастосування : монографія. Київ : НУБіП України, 2019. 294 с

2. Скакун О.Ф. Теорія права $і$ держави : підручник; вид. 4-те, допов. $i$ переробл. Київ : Правова єдність, 2013. 524 с.

3. Конститущія України : Закон Украіни від 28 червня 1996 р. № 254к/96-ВP / Верховна Рада України. Відомості Верховної Ради України. 1996. № 30. Cm. 141.

4. Додин Е.В. Административная ответственность в свете Конституизии Украины. Юридичний вісник. 1997. № 3. C. 70-74

5. Кодекс України про адміністративні правопорушення : Закон Української РСР від 7 грудня 1984 р. № 8073-Х. Відомості Верховної Ради Української РСР. 1984. № 51. Cm. 112 .
6. Митний кодекс України : Закон України від 13 березня 2012 р. № 4495-VI. Відомості Верховної Ради України. 2012. № № 44-45, 46-47, 48. Сm. 552 .

7. Податковий кодекс України : Закон України від 2 грудня 2010 р. № 2755-VI. Відомості Верховної Ради України. 2011. № № 13-14, 15-16, 17. Cm. 112 .

8. Филь С.П. Правове регулювання захисту прав інтелектуальнӧ власності у сфері митної діяльності в Україні : автореф. дис. ... канд. юрид. наук. Київ : ДНДІ МВС України, 2017. 21 с.

9. Господарський кодекс України : Закон України від 16 січня 2003 р. № 436-IV. Відомості Верховної Ради України. 2003. № № 18, $19-20,21-22$. Cm. 144 .

10. Світличний О.П. Метод як один із елементів змісту управлінської діяльності у сфері інтелектуальної власності. Науковий вісник Національного університету біоресурсів $і$ природокористування України. Серія «Право». 2017. № 264. С. 33-38.

11. Про рекламу : Закон України від 3 грудня 1996 р. № 270/96-ВР. Відомості Верховної Ради України. 1996. № 39. Cm. 181 .

12. Про державне регулювання виробниитва $і$ обігу спирту етилового, коньячного $i$ плодового, алкогольних напоїв, тютюнових виробів та пального : Закон України від 19 грудня 1995 р. № 481/95-ВР. Відомості Верховної Ради України. 1995. № $46 . \mathrm{Cm}$. 345 .

13. Про заходи щодо попередження та зменшення вживання тютюнових виробів $i$ іх шкідливого впливу на здоров'я населення : Закон України від 22 вересня 2005 р. № 2899-IV. Відомості Верховної Ради України. 2005. № 52. Сm. 565.

14. Про захист економічної конкуренції : Закон України від 11 січня 2001 р. № 2210III. Відомості Верховної Ради України. 2001. № 12. Cm. 64 .

15.Про захист від недобросовісної конкуренції : Закон України від 7 червня 1996 р. № 236/96-ВР. Відомості Верховної Ради України. 1996. № 36. Cm. 164.

16. Порядок накладення штрафів за порушення законодавства про рекламу: Постанова Кабінету Міністрів України від 26 травня 2004 р. № 693 (в редакції постанови № 885 віо 26 вересня 2012 р.). URL: https: / / zakon. rada. gov.ua/ laws/ show/ 693-2004-n. 